\title{
EVALUATING THE EFFICIENCY OF HOUSEHOLD STORMWATER DETENTION SYSTEM
}

\author{
Johnny Ong King Ngu ${ }^{1}$, Darrien Yau Seng Mah ${ }^{1}$, Siti Noor Linda Taib ${ }^{1}$, Md Abdul \\ Mannan', and Siew Liang Chai ${ }^{2}$ \\ ${ }^{1}$ Faculty of Engineering, Universiti Malaysia Sarawak, Kota Samarahan, Malaysia \\ ${ }^{2}$ WenHong Plastic Industries Sdn. Bhd., Kuching, Malaysia, e-mail: johnnyngu91@gmail.com
}

Received Date: April 21, 2020; Revised Date: August 2, 2020; Acceptance Date: October 16, 2020

\begin{abstract}
This paper describes the evaluation of water storing capacity of a household stormwater detention system based on field data. Collection of field data is often sidelined due to the cost and human capital incurred. However, the true value of field data is demonstrated here by comparing the observed and design data. A field test is completed in a real-life terrace house, utilizing the house's $95 \mathrm{~m}^{2}$ side canopy as roof catchment and $4.40 \mathrm{~m} \times 4.70 \mathrm{~m}$ car porch area to station a detention tank. Precast concrete modular units with $3.9 \mathrm{~m}^{3}$ effective storage volume are assembled within the tank. Downpipe with $0.1 \mathrm{~m}$ diameter is installed to connect the roof gutter to the detention tank; while pipeline with $0.05 \mathrm{~m}$ diameter is installed as the outlet from tank to the house perimeter drain. The mentioned setup is subjected to actual rainfalls from December 2019 till February 2020 that corresponded with the peak of Northeast Monsoon season. Ten observed storm events with peak hourly total rainfall readings ranging from 22 to $48 \mathrm{~mm}$ are selected for analysis. Rainfall and water level readings from the field test allow the derivation of roof runoff volume and detained water volume in the tank. It is found that the household stormwater detention system is able to capture about $50 \%$ of the roof runoff. However, the current setup is found to cause flooding for rainfall over $40 \mathrm{~mm}$. The flooding issue, however, is undetected by the design data that underestimated the water storing capacity. This is due to the use of uncommon precast concrete modular units that may not have its flow characteristics represented by existing formula and model. No matter how uncommon the modular units be, various types and forms of stormwater detention system are becoming the new normal in the industry and field test is the best tool to validate their performances.
\end{abstract}

Keywords: Field test, On-site detention, Runoff, Stormpav, Urban drainage, Water level

\section{Introduction}

Stormwater detention systems are manmade facilities to stop and store urban surface water in an identified spot from running in the towns or cities [1],[2]. In the context of this paper, it is a detention system specifically designed for household application (Figure 1). The concept is to have each household to capture parts of running water within their car porch, so that a large accummulated water from a human settlement could be delayed into the urban environment [3],[4]. This could mitigate the happening of flash flood and soil erosion [5]. As such, the main performance for such a system is its water storage capability [6], in which this paper is evaluating the detention volume of a household stormwater detention system using field data. 
a)

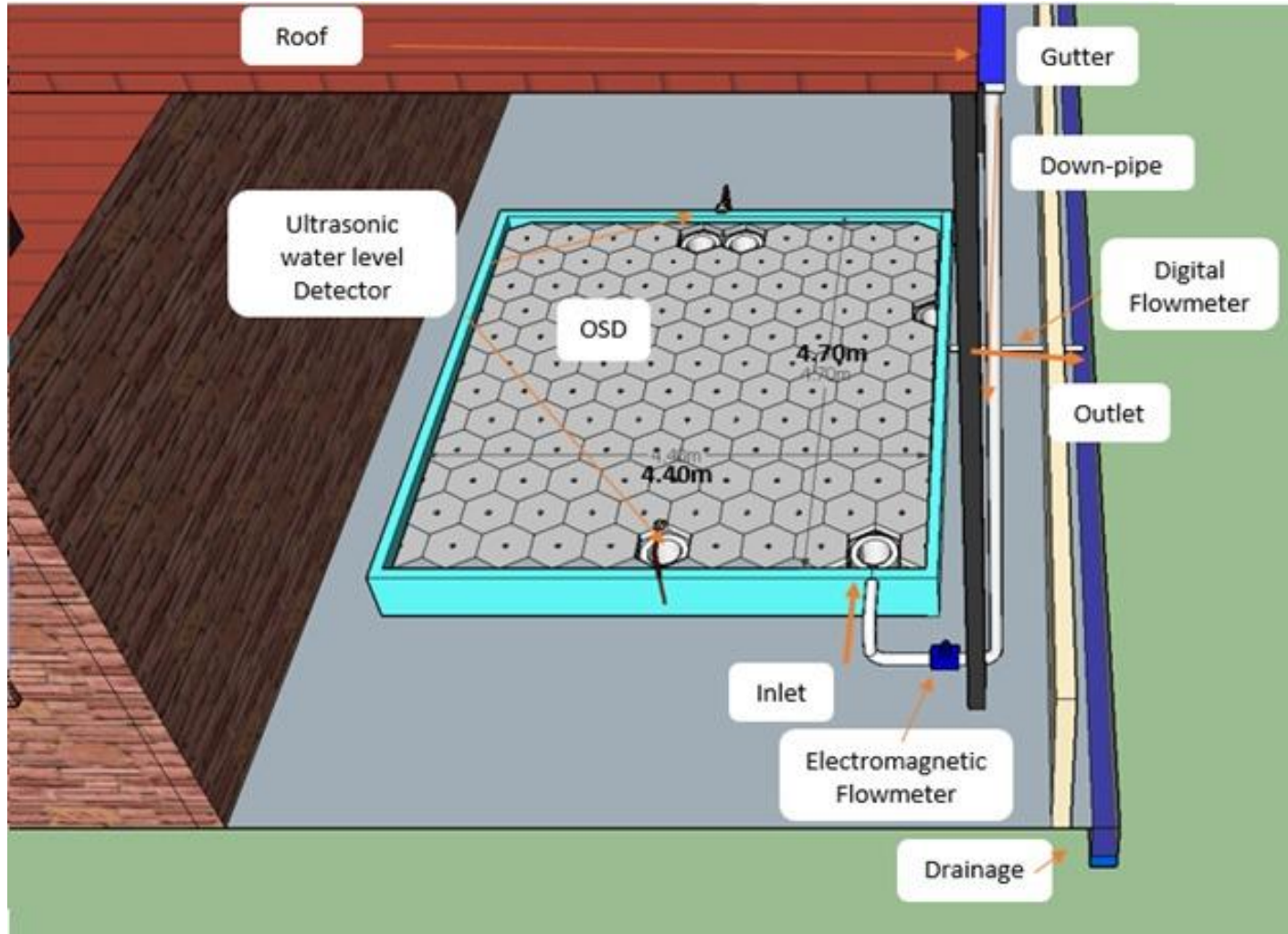

b)

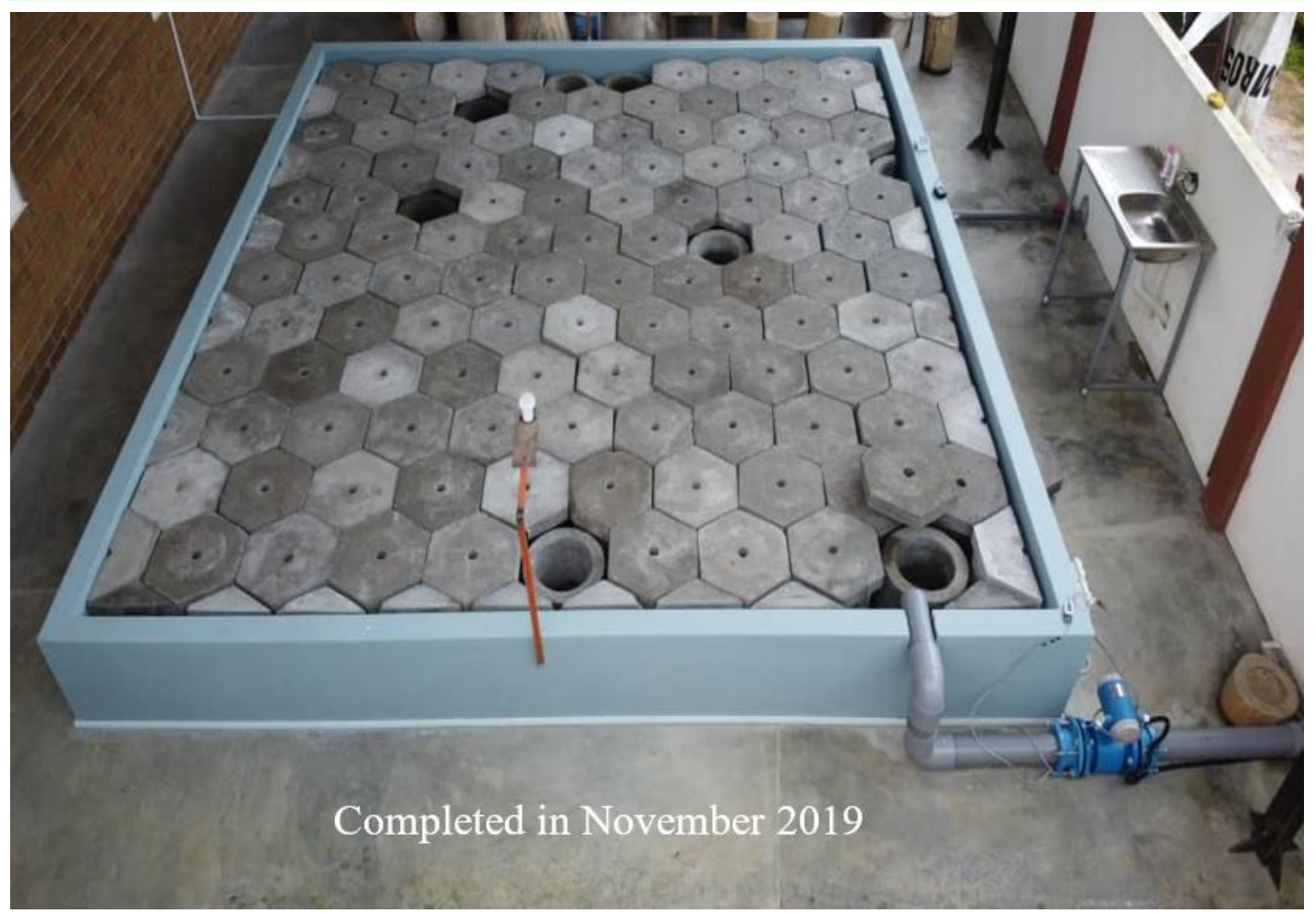

Figure 1. Household stormwater detention system, a) Sketchup 3D drawing, and b) Actual field test

A field test depicted in Figure 1 is constructed within a terrace house in Kuching city, Sarawak, Malaysia with the permission of the property owner. By design, it is supposed to be underground. It is erected on the existing car porch's concrete surface for easy removal later. Parts of the house's roof $\left(95 \mathrm{~m}^{2}\right)$ that could drain water to the car 
porch is delineated as the catchment. The surface area occupied by the detention system is $4.40 \mathrm{~m} \times 4.70 \mathrm{~m}$ that allows the parking of two cars. Within the system, it is laid with a series of precast concrete modular units, in which the product is named StormPav Green Pavement System, or in short, StormPav [7],[8]. The depth of the system is $0.45 \mathrm{~m}$, illustrated in Figure 2 as the total height of a single StormPav modular unit.
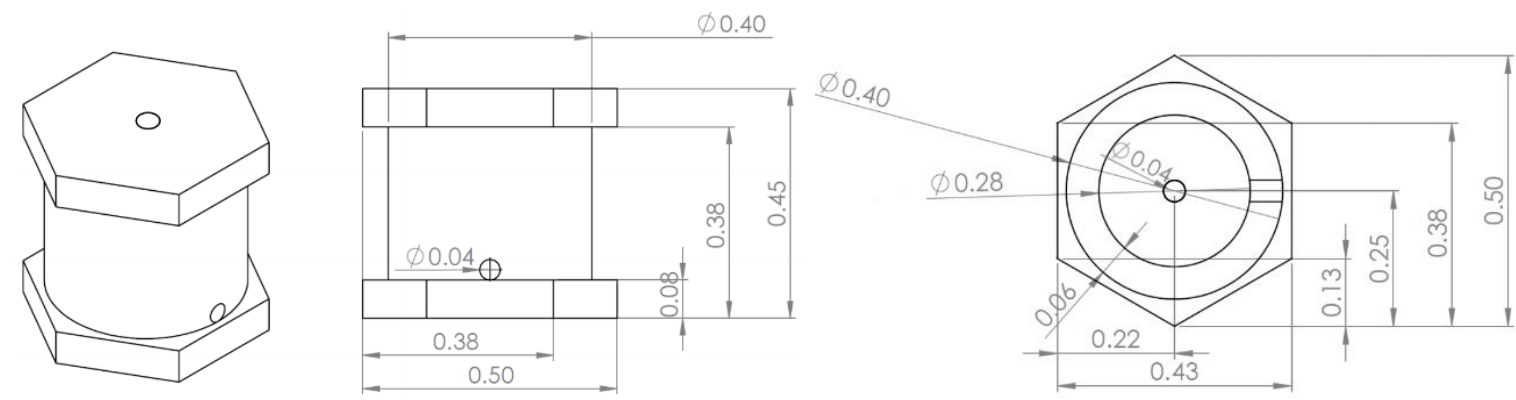

Figure 2. StormPav Green Pavement System

\section{Materials and Methods}

\section{Engineering Design}

Referring to Figure 3 as a guide, a simple rectangular stormwater detention tank receives water from an inlet and discharges water through an outlet. According to the Law of Mass Conservation, the inflow of the tank, $Q_{\text {in }}$ equals to outflow, Qout. As the roof is $100 \%$ impervious, the rainfall is $100 \%$ converted to runoff with an assumption that loss is negligible.

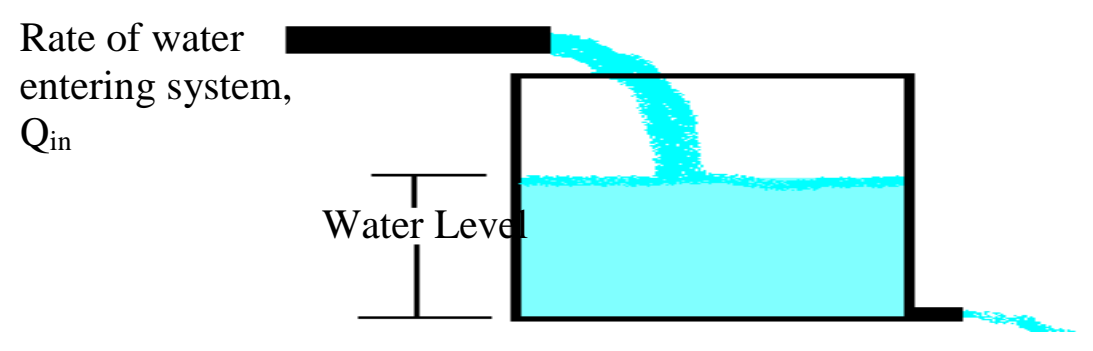

\section{Law of Mass \\ Conservation \\ $\mathrm{Q}_{\text {in }}=\mathrm{Q}_{\text {out }}$}

Rate of water

leaving system,

Qout

Figure 3. Schematics of Stormwater Detention Tank

Previous studies [3],[4] with similar roof catchment and tank sizes have simulated flows through the inlet and inlet with circular pipe sizes available in the market. The roof runoff is channelled to $0.1 \mathrm{~m} \times 0.1 \mathrm{~m}$ roof gutter and $0.1 \mathrm{~m}$ diamater downpipe that is tested to avoid surcharges. The downpipe also functions as the inlet to the household stormwater detention system. A $0.05 \mathrm{~m}$ diameter pipeline functions as the outlet that is tested to avoid flow congestion. By having a smaller outlet size, $Q_{\text {out }}$ is intentionally made small so that slow release is obtained and in return, a water detention is achieved.

To maintain the mass conservation due to the relatively higher $\mathrm{Q}_{\text {in, }}$, the water level due to the water mass confined by the geometry of the tank increases. For an empty tank, by knowing the surface area occupied by the tank, a water level reading could give 
the water mass (or volume of detained water) associated with the water level at the time of reading. In this case with the tank being filled with precast concrete modular units, its effective storage volume is applied by substracting the volume of solid concrete from gross tank volume [9].

The procedures for designing a stormwater detention system are referred to design manuals in [10],[11]. For a stormwater system intended for household purposes, it is defined as a minor system designed to 10-year average recurrent interval (ARI). The design rainfall values are calculated based on a polynomial approximation equation for Kuching city provided by the Malaysian Department of Irrigation and Drainage [11]. As the $95 \mathrm{~m}^{2}$ roof is considered as small catchment, it is suggested to consider short design storm durations between 5 to 15 minutes. Its design parameters are calculated and presented in Table 1.

Table 1. Stormwater Detention Design due to 10-year ARI Design Rainfall

\begin{tabular}{|c|c|c|c|c|c|c|c|}
\hline $\begin{array}{c}\text { Rainfall } \\
\text { Intensity }\end{array}$ & $\begin{array}{c}\text { Storm } \\
\text { Duration } \\
\text { (Min) }\end{array}$ & $\begin{array}{c}\text { Design } \\
\text { Rainfall } \\
\text { Depth } \\
\mathbf{( m m )}\end{array}$ & $\begin{array}{c}\text { Inflow } \\
\left(\mathbf{m}^{\mathbf{3}} / \mathbf{s}\right)\end{array}$ & $\begin{array}{c}\text { Outflow } \\
\left(\mathbf{m}^{\mathbf{3}} \mathbf{s}\right)\end{array}$ & $\begin{array}{c}\text { Roof } \\
\text { Runoff } \\
\text { Volume } \\
\left.\mathbf{( m}^{\mathbf{3}}\right)\end{array}$ & $\begin{array}{c}\text { Water } \\
\text { Level in } \\
\text { Tank }(\mathbf{m})\end{array}$ & $\begin{array}{c}\text { Calculated } \\
\text { Detained } \\
\text { Water }\left(\mathbf{m}^{\mathbf{3}}\right)\end{array}$ \\
\hline $\begin{array}{c}\text { 10-year } \\
\text { ARI }\end{array}$ & 5 & 23 & 0.007 & 0.0005 & 2.19 & 0.22 & 2.03 \\
\cline { 2 - 8 } & 10 & 36 & 0.006 & 0.0006 & 3.42 & 0.28 & 2.58 \\
\hline
\end{tabular}

Based on Table 1, the 5-min 10-year ARI design rainfall is estimated at $23 \mathrm{~mm}$ that resulted in $0.22 \mathrm{~m}$ design water level and $2.03 \mathrm{~m}^{3}$ water storage $(93 \%$ of roof runoff is captured). The 10-min 10-year ARI design rainfall is estimated at $36 \mathrm{~mm}$ that resulted in $0.28 \mathrm{~m}$ design water level and $2.58 \mathrm{~m}^{3}$ water storage ( $75 \%$ of roof runoff is captured). Lastly, the 15-min 10-year ARI design rainfall is estimated at $46 \mathrm{~mm}$ that resulted in $0.35 \mathrm{~m}$ design water level and $3.22 \mathrm{~m}^{3}$ water storage ( $74 \%$ of roof runoff is captured).

\section{Observed Rainfall}

A rain gauge is installed at the field test site to record the actual rainfall on the roof. The period is from December 2019 to February 2020, in which the three months are coincided with the Northeast Monsoon experienced in this region. These are the wettest months in Sarawak [12]. Based on Figure 4, three marks are set at 20,30 and 40mm. It is observed $90 \%$ of the hourly total rainfalls are below $20 \mathrm{~mm}, 5 \%$ between $20-30 \mathrm{~mm}, 4 \%$ between $30-40 \mathrm{~mm}$ and $1 \%$ between $40-50 \mathrm{~mm}$.

These hourly total rainfall groups are created in line with the design rainfall depths in Table 1 . The $20-30 \mathrm{~mm}$ group is close to the 5-min 10-year ARI design rainfall $(23 \mathrm{~mm})$. The $30-40 \mathrm{~mm}$ group is close to the 10 -min 10 -year ARI design rainfall $(36 \mathrm{~mm})$, while the the $40-50 \mathrm{~mm}$ is close to the 15 -min 10-year ARI design rainfall $(46 \mathrm{~mm})$. The $0-20 \mathrm{~mm}$ group is lower than the range of determined design rainfall depths, and therefore excluded for further analysis. 
a)

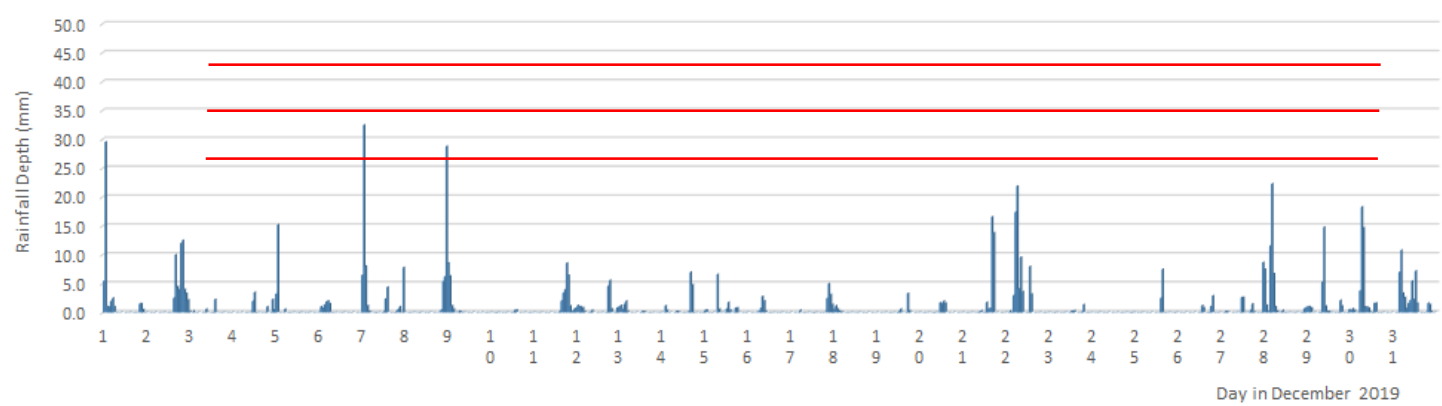

b)

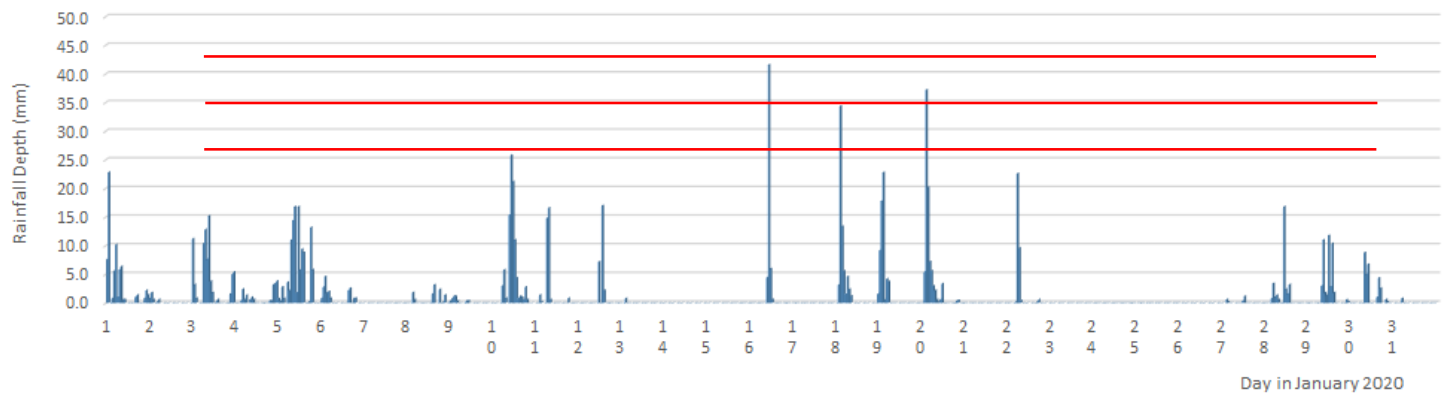

c)

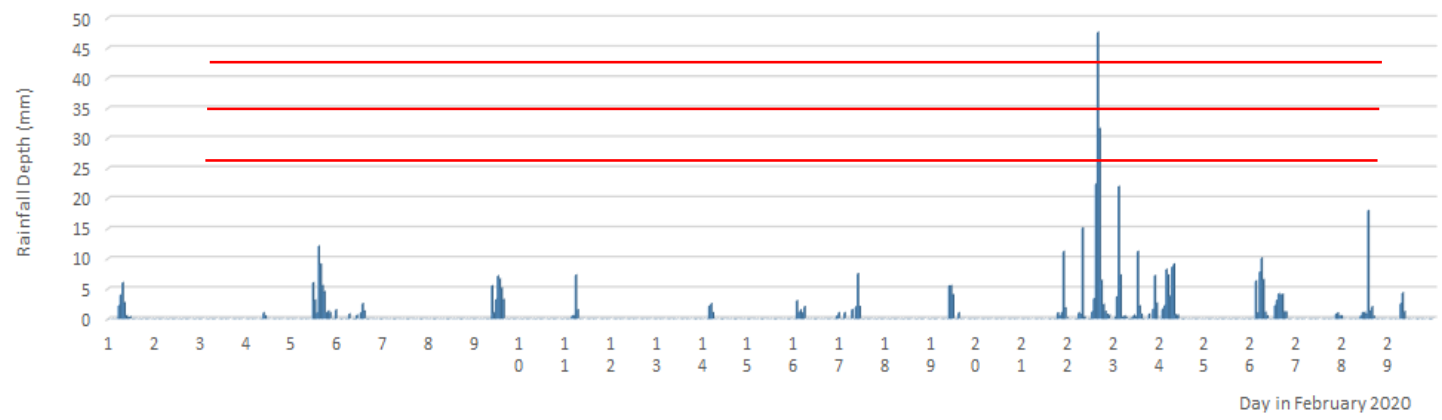

Figure 4. Hourly Total Rainfall Patterns for a) December 2019, b) January 2020 and c) February 2020

\section{Observed Water Level}

A level sensor is installed in the household stormwater detention tank to record the rise and fall of water level in the tank. Although the tank, in this case, is filled with precast concrete modular units, these units are not sealed or glued together but each rests freely on each others. The modular units are designed as such for maintenance purposes that allow the unit to be change if required. The detained water is observed to take the shape of the tank, and the water level readings are uniform at four corners of the tank $[3],[13],[14]$.

\section{Results and Discussion}

Ten observed storm events are presented in Figure 5, highligting its hourly total rainfall hyetographs (in bars) and resulted hourly water level hydrographs (in lines) for each storm event. The observed peak hourly total rainfalls range from 22 to $48 \mathrm{~mm}$, while the observed peak hourly water levels range from 0.2 to $0.5 \mathrm{~m}$. 
a)

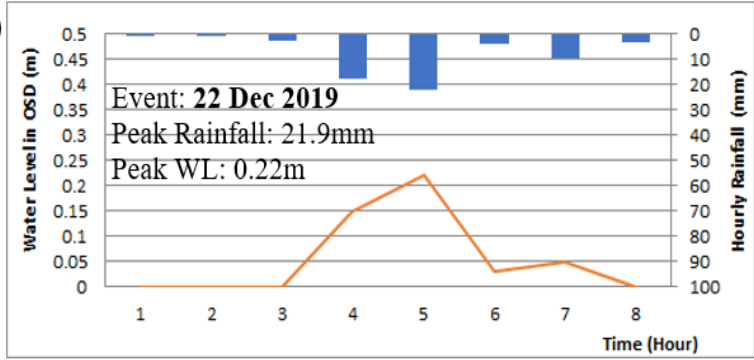

c)

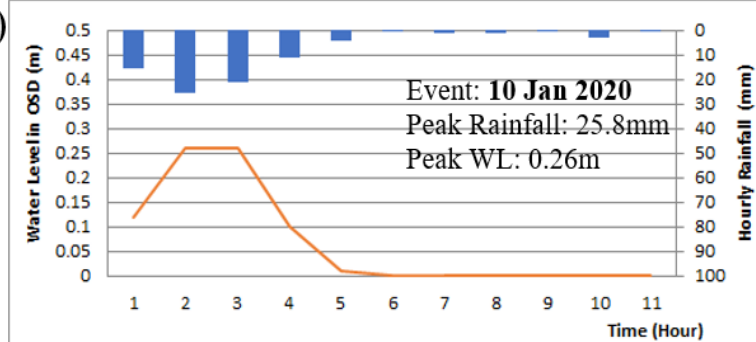

e)

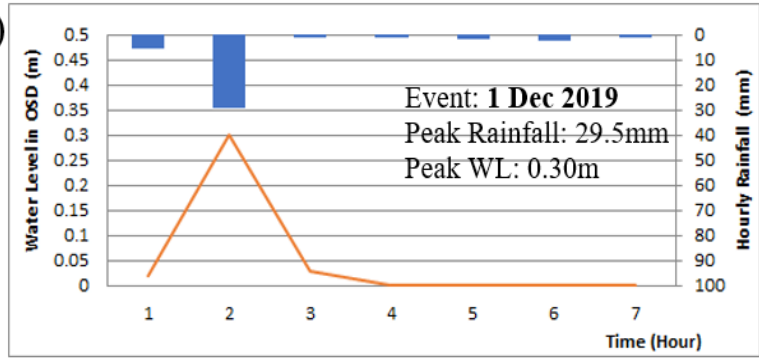

g)

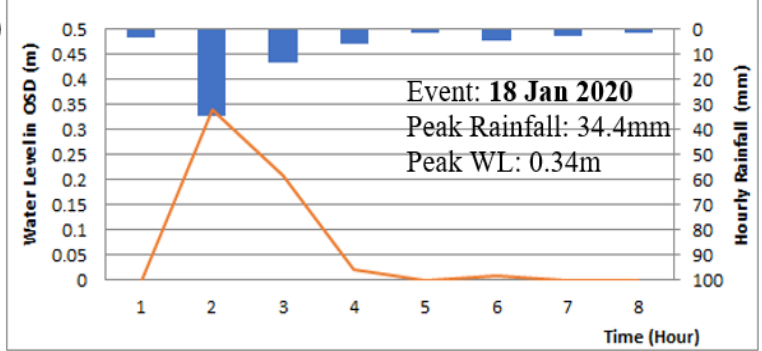

i)

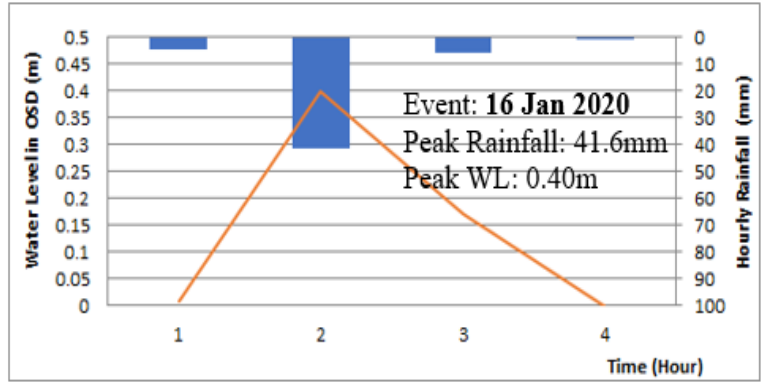

b)

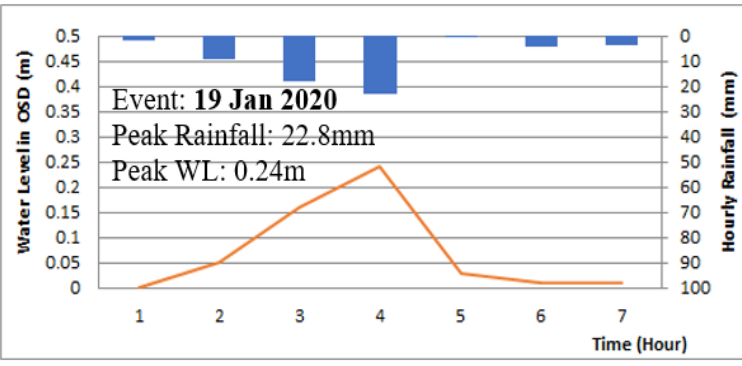

d)

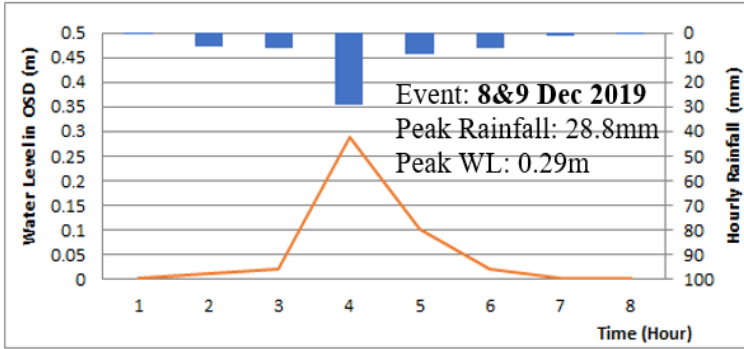

f)

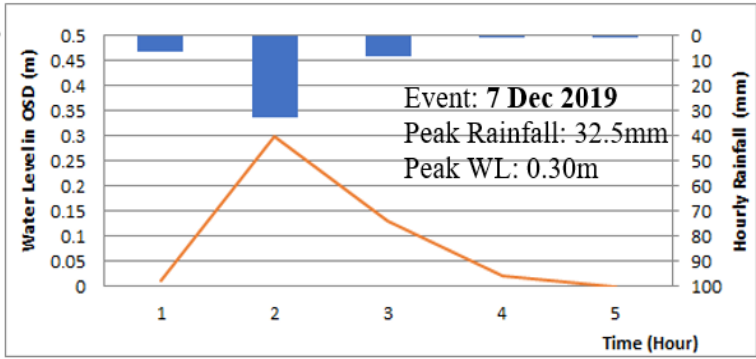

h)

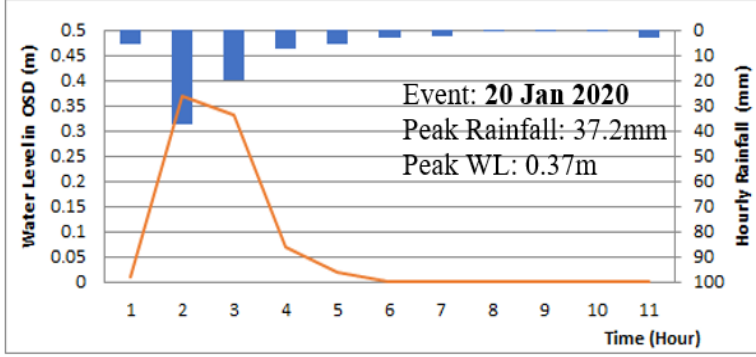

j)

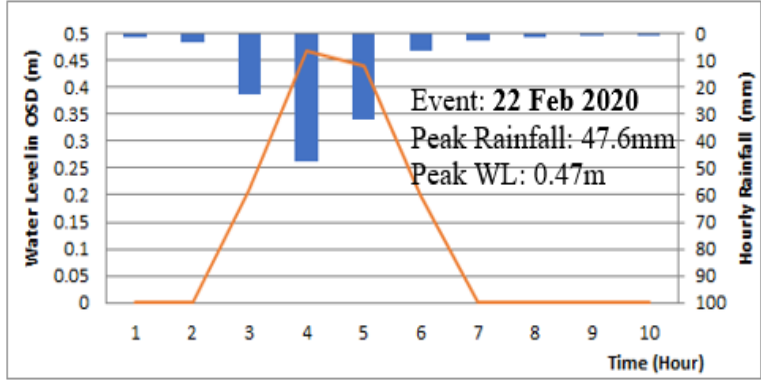

Figure 5. Observed Hourly Total Rainfall Hydrograph and Hourly Water Level Hydrograph for a) 22 December 2019, b)19 January 2020, c) 10 January 2020, d) 8\&9 December 2019, e) 1 December 2019, f) 7 December 2019, g) 18 January 2020, h) 20 January 2020, i) 16 January 2020 and j) 22 February 2020 Storm Events

A summary of the selected ten storm events are tabulated in Table 2. These include observed data (peak rainfall, total rainfall and water level) and calculated data (roof runoff volume, detained water volume and percentage of roof runoff being captured). 
Table 2. Parameters for Observed Storm Events

\begin{tabular}{|c|l|c|c|c|c|c|c|}
\hline No & Storm Event & $\begin{array}{c}\text { Peak } \\
\text { Hourly } \\
\text { Total } \\
\text { Rainfall } \\
(\mathbf{m m})\end{array}$ & $\begin{array}{c}\text { Total } \\
\text { Rainfall } \\
\text { per } \\
\text { Storm } \\
(\mathbf{m m})\end{array}$ & $\begin{array}{c}\text { Roof } \\
\text { Runoff } \\
\text { Volume } \\
\left(\mathbf{m}^{\mathbf{3}} \mathbf{)} *\right.\end{array}$ & $\begin{array}{c}\text { Peak } \\
\text { Water } \\
\text { Level } \\
\text { in } \\
\text { Tank } \\
\mathbf{( m )}\end{array}$ & $\begin{array}{c}\text { Calculated } \\
\text { Detained } \\
\text { Water } \\
\left(\mathbf{m}^{\mathbf{3}} \mathbf{)}\right.\end{array}$ & $\begin{array}{c}\text { Remarks } \\
\mathbf{( \% ~ o f ~} \\
\text { Roof } \\
\text { Runoff) } \\
*\end{array}$ \\
\hline 1 & 22 Dec 2019 & 21.9 & 60.0 & 5.70 & 0.22 & 2.03 & 36 \\
\hline 2 & 19 Jan 2020 & 22.8 & 60.0 & 5.70 & 0.24 & 2.21 & 39 \\
\hline 3 & 10 Jan 2020 & 25.8 & 84.8 & 8.06 & 0.26 & 2.39 & 30 \\
\hline 4 & 8\&9 Dec 2019 & 28.8 & 57.8 & 5.49 & 0.29 & 2.67 & 49 \\
\hline 5 & 1 Dec 2019 & 29.5 & 42.5 & 4.04 & 0.30 & 2.76 & 68 \\
\hline 6 & 7 Dec 2019 & 32.5 & 48.5 & 4.61 & 0.30 & 2.76 & 60 \\
\hline 7 & 18 Jan 2020 & 34.4 & 66.4 & 6.31 & 0.34 & 3.13 & 50 \\
\hline 8 & 20 Jan 2020 & 37.2 & 85.6 & 8.13 & 0.37 & 3.41 & 42 \\
\hline 9 & 16 Jan 2020 & 41.6 & 52.6 & 5.00 & 0.40 & 3.68 & 74 \\
\hline 10 & 22 Feb 2020 & 47.6 & 117.5 & 11.16 & 0.47 & 4.33 & 39 \\
\hline
\end{tabular}

Note: * By calculation

These selected storms are mostly from December 2019 and January 2020. One can observe in Figure 4 that the monsoon season peaks in the said two months. December has a monthly total rainfall $687.3 \mathrm{~mm}$ and January, $883.4 \mathrm{~mm}$. The following month of February has a drastic drop to $499.9 \mathrm{~mm}$ but the month has the most heavy storm event on 22 February, which is selected as storm event No 10 in Table 2.

The storm events are arranged from No 1 to 10 according to its peak hourly total rainfalls. Engineering hydrology stresses on the peak rainfall, peak flow and peak water level. Although flow hydrograph is excluded, one can observe in Figure 5 that the peak hourly total rainfalls (the longest bar) and the peak hourly water levels (the highest tips of lines) are the most prominent features. Thus, it is a common practice to refer an event based on its peak. For example, $21.9 \mathrm{~mm}$ peak hourly total rainfall of storm event No 1 (22 December 2019) could be relate to the $23 \mathrm{~mm}$ design rainfall of 5-min 10-year ARI. In this case, all storm events display both peaks at the same time frame, in which it may not be so in other cases.

However, each of the storm lasts for different time spans, from 4 hours to 11 hours in Figure 5. When the hourly total rainfall of an individual storm event is added up, it results in the total rainfall per storm. It is demonstrated that storm events under the same group have a diverse values in total rainfall per storm. Referring to storm events No 1 to 5 , the 1 December 2019 event has a total rainfall per storm of $42.5 \mathrm{~mm}$. Even though the event has the highest peak rainfall among the five events but it is found with the least total rainfall. This is the reality of actual rainfall that is non-uniformly distributed in nature.

The total rainfall per storm values are needed to calculate the amount of roof runoff volume by multiplying the accumulated rainfall depth with the roof area. Whilst, the observed hourly water levels are needed to calculate the amount of detained water in the tank. Percentages of how much roof runoffs that are being captured in the detention tank are also provided in Table 2.

The percentages tabulated are varied from storm to storm. Logically, the smaller the total rainfall per storm, the less the generated roof runoff, and this lesser amount of roof runoff when detained constitutes to a higher percentage of detention. This is the case of storm 
event No 5. The larger the total rainfall per storm, the more the generated roof runoff that is observed to overwhelm the existing capacity of detention tank. This could be observed in storm event No 10, in which this event has the largest total rainfall per storm but having a lesser achievement in detention volume.

Generally, the percentages of roof runoff captured range from the lowest $30 \%$ (storm event No 3) to the highest 68\% (storm event No 5). A pattern could be observed that the household stormwater detention system could detain an average of $48.7 \mathrm{~m}^{3}$ of runoff, close to $50 \%$ based on the selected ten storm events. This observation is bounded by the existing setup of catchment, tank, inlet and outlet under $20-50 \mathrm{~mm}$ of rainfall.

The design detention volumes in Table 1 are plotted together with the detention volumes derived from the field data in Table 2 for comparison. Figure 6 shows the two datasets, namely the design detention volumes are termed as design dataset in square markers and dotted line; while the detention volumes derived from field data are termed as field datasets in circular markers and solid line. Another mark is added to indicate the maximum effective storage of the detention tank at $3.9 \mathrm{~m}^{3}$.

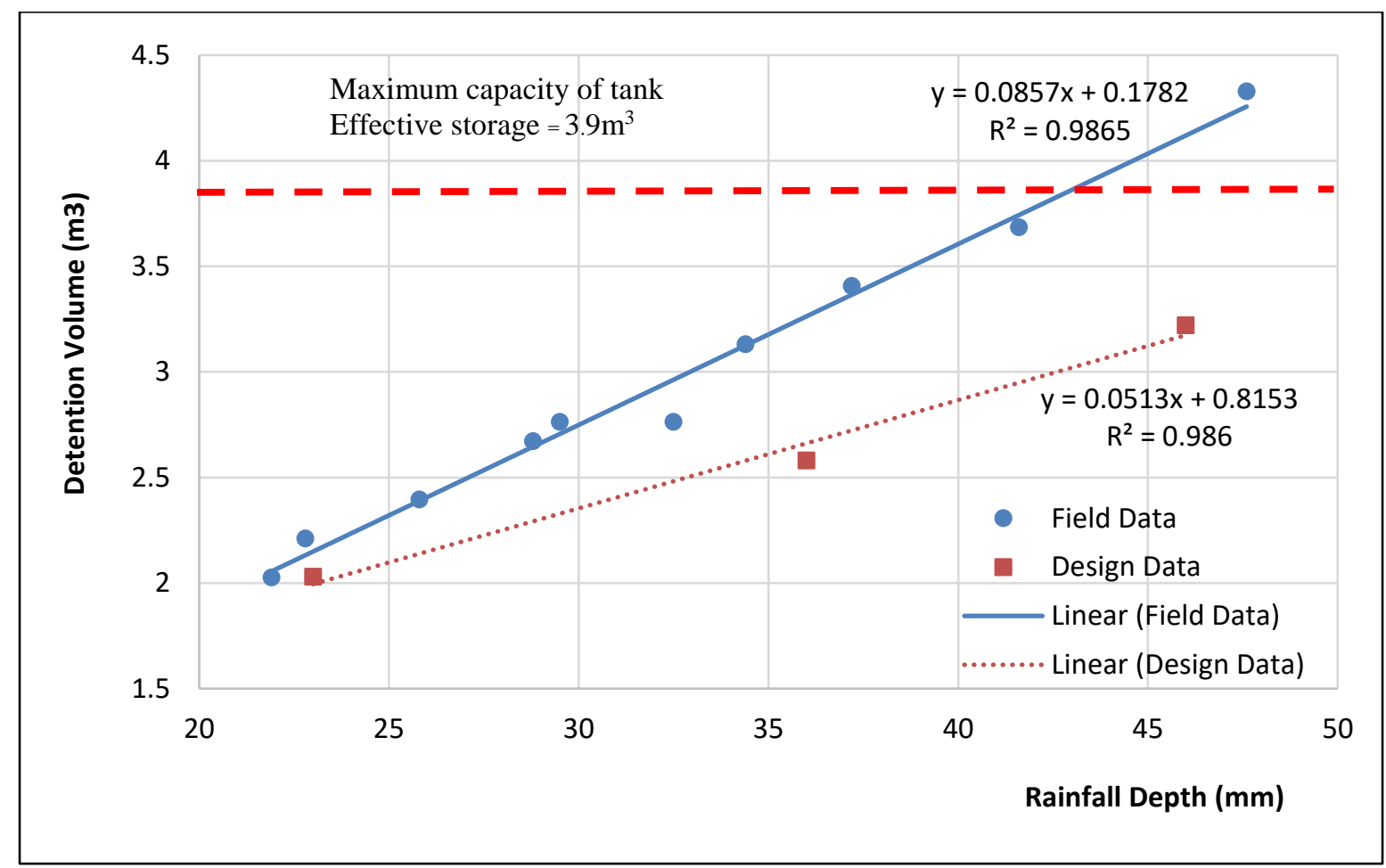

Figure 6. Detention Volumes according to Observed Rainfall Depths

At one glance, it is clearly indicated that the design dataset are underestimated for having all its data points lower than the other dataset. The field dataset are not without fault. One point from the field dataset is exceeding the maximum tank capacity (storm event No 10) and another point is too near to the maximum tank capacity (storm event No 9). It indicates that the existing setup of the household stormwater detention system is posing flood risk to its end users once the system receives rainfall over $40 \mathrm{~mm}$. Improvement is needed to lower the field dataset so that no near or exceeding of maximum tank capacity to occur. This observation is similar to the finding of [15] that stresses the importance of field monitoring to validate the design data. 


\section{Conclusions}

The evaluation of household stormwater detention system is made possible with the availability of a fied test. The field test allows the collection of first-hand data in terms of the amount of rainfall, rate of water entering and leaving the system as well as the water level in the tank. However, there are parameters that could not be measured directly. The amount of roof runoff generated and the amount of water detained in the tank are derived from the field data. On top of these data, it should be noted the detention system is limitted by its current setup of roof catchment, effective storage of tank, the inlet and outlet sizes. In the sense of the mentioned limitations, it is found the household stormwater detention system is able to detain in average about $50 \%$ of runoff generated from the contributing catchment.

Being designed to 5-15 minutes short design storm durations, the system is expected to withstand the magnitudes of runoff generated by these design storm durations. The observed storm events, however, demonstrate that the system is only safe for 5- and 10minute storm durations that equivalent to 23 and $36 \mathrm{~mm}$ rainfall depths respectively. It is found unsafe for having overflow of floodwaters in 15-minute storm duration that equivalent to $46 \mathrm{~mm}$ rainfall depth. Although by comparison of occurrence frequency that the over $40 \mathrm{~mm}$ rainfall depth storms constitutes to only $1 \%$, improvement is needed as to ensure the comfortability and to boost the confident of end users.

\section{Acknowledgement}

The authors acknowledged the financial support from the Post-Graduate Research Grant Scheme (Project ID F02/PGRG/1911/2019) rendered by Universiti Malaysia Sarawak.

\section{References}

[1] R. Ronalds, and H. Zhang, "Assessing the impact of urban development and on-site stormwater detention on regional hydrology using Monte Carlo simulated rainfall," Water Resources Management, Vol. 33, pp. 2517-2536, 2019.

[2] R. Segarra-Garcia, "Reliability-based design of urban stormwater detention facilities with random carryover storage," Journal of Water Resources Planning and Management, Vol. 146, No. 2, 2020. doi: 10.1061/(ASCE)WR.1943-5452.0001166

[3] J.O.K. Ngu, D.Y.S. Mah, and C.H.J. Bong, "Flow characteristics of individual lot stormwater detention," Water Practice and Technology, Vol. 11, No. 4, pp. 721-727, 2016.

[4] J.O.K. Ngu, D.Y.S. Mah, C.V. Liow, and I.T. Ngu, "Modelling of on-site stormwater detention underneath a car porch," International Journal of Innovative Technology and Exploring Engineering, Vol. 8, No. 12, pp. 4304-4307, 2019.

[5] F. Li, X.-F. Yan, and H.-F. Duan, "Sustainable design of urban stormwater drainage systems by implementing detention tank and LID measures for flooding risk control and water quality management," Water Resources Management, Vol. 33, pp. 32713288, 2019.

[6] S.B. MacLean, A. Vytiniotis, and D.W. Sykora, "Laboratory testing and engineering analysis of an underground stormwater detention system," Geo-Congress, February 25-28, Minneapolis, Minnesota, 2020, doi: 10.1061/9780784482827.007

[7] M.A. Mannan, N. Bateni, D.C.L. Teo, D.Y.S. Mah, F. J. Putuhena, C.K. Ng, R.A. Bustami, W.H.W. Ibrahim, C.L.F. Lee, and H.L. Lim, System and Method of Green Pavement, Application Number PI2016704420, Malaysian Intellectual Property Corporation, Kuala Lumpur, 2016. 
[8] D.Y.S. Mah, Potential of Road Subsurface On-Site Stormwater Detention System, Universiti Malaysia Sarawak Publisher, Kota Samarahan, Sarawak, Malaysia, 2016.

[9] D.Y.S. Mah, J.O.K. Ngu, S.N.L. Taib, and M.A. Mannan, "Modelling of compartmentalized household stormwater detention system using SWMM5," International Journal of Emerging Trends in Engineerng Research, Vol. 8, No. 2, pp. 344-349, 2020.

[10] Public Utilities Board of Singapore, Technical Guide for On-Site Storm Water Detention Tank Systems, National Water Agency, Singapore, 2010.

[11] Department of Irrigation and Drainage Malaysia, Urban Stormwater Management Manual for Malaysia, Percetakan Nasional Malaysia, Kuala Lumpur, Malaysia, 2012.

[12] Z. Sa'adi, S. Shahid, T. Ismail, E.-S. Chung, and X.-J. Wang, "Distributional changes in rainfall and river flow in Sarawak, Malaysia," Asia-Pacific Journal of Atmospheric Sciences, Vol. 53, pp. 489-500, 2017.

[13] D.Y.S. Mah, M.A. Mannan, and W.H.W. Ibrahim, "Pilot study of StormPav Green Pavement System," International Journal of Research in Engineering and Advanced Technology, Vol. 6, No. 5, pp. 29-35, 2018.

[14] N. Bateni, S.H. Lai, F.J. Putuhena, D.Y.S. Mah, M.A. Mannan, and R.J. Chin, "Hydrological performances on the modified permeable pavement with precast hollow cylinder micro detention pond structure," KSCE Journal of Civil Engineering, Vol. 23, pp. 3951-3960, 2019.

[15] P.D.P. Drumond, P.M. Moura, and M.M.L.P. Coelho, "Comparison the monitoring data of an on-site stormwater detention (OSD) and the results in the use of theoretical methods for its design," Brazilian Journal of Water Resources, Vol. 23, e18, 2018. 